\title{
GELEŽINKELIO EISMO VALDYMO SISTEMŲ TYRIMAS
}

\author{
Darius Gaidelis ${ }^{1}$, Šarūnas Mikaliūnas ${ }^{2}$ \\ Vilniaus Gedimino technikos universitetas \\ El.paštas: ${ }^{1}$ d.gaidelis@litrail.lt; ${ }^{2}$ sarunas.mikaliunas@vgtu.lt
}

\begin{abstract}
Santrauka. Straipsnyje lyginamos geležinkelyje naudojamos eismo valdymo sistemos. Analizuojami jų privalumai ir trūkumai. Apžvelgta ịvairiose šalyse naudojamų geležinkelio eismo valdymo sistemų raida bei aptariamas tolesnis jų plètojimas. Analizuojamos šių mikroprocesorinių eismo valdymo sistemų pritaikymo Lietuvoje galimybès. Siekiant pagrįstai tai išsiaiškinti atlikta Lietuvos geležinkeliais vežtų krovinių analizè ir įvertintas ịvairiais kelio ruožais vežtų kroviniu skaičiaus netolygumas. Analizuota kiek traukinių sulaikyta dèl eismo valdymo sistemų gedimų per paskutinius kelerius metus. Apskaičiuotos naujai įrengiamos mikroprocesorinès eismo valdymo sistemos įdiegimo geležinkelio stotyje sąnaudos bei šių sistemų atsipirkimo laikas ir darbuotoju poreikis.
\end{abstract}

Reikšminiai žodžiai: geležinkelių transportas, eismo valdymo sistemos.

\section{Ivadas}

Geografinè padètis nulèmè, kad Lietuva yra tranzito kraštas, nors ir nedidelis, bet reikšmingas ruožas RytųVakarų geležinkelių linijoje. Tai patvirtina ir beveik 150 metų Lietuvos geležinkelio istorija, gana tiksliai atitinkanti XIX-XX amžiaus Lietuvos istorinius, ekonominius, politinius îvykius. Karai bei revoliucijos, derinę visos mūsų šalies raidą prie stiprių Rytų ir Vakarų valstybių poreikių, „persiuvinejo“ ir Lietuvos geležinkelio vėžès ploti pagal Rusijos ar Vakarų Europos reikalavimus.

Geležinkelių automatikos sistemos - tai techninès priemonès, užtikrinančios saugų traukinių eismą ir automatizuojančios jų valdymą. Jas sudaro geležinkelių stočių ir tarpstočių automatikos signalizacijos irenginiai (SI), kuriuos naudojant rengiami traukinių maršrutai, valdomas ir kontroliuojamas traukinių eismas.

Šiuo metu eismas Lietuvos geležinkeliais valdomas Rusijoje suprojektuotomis ir pagamintomis relinès signalizacijos sistemomis. Nustatyta, kad dauguma šios sistemos irenginiu pasenę: apie $40 \%$ jų eksploatuojami jau 30 metų, kiti $40 \%$ - 20 metų ir tik $20 \%$ stočių signalizacijos irrenginių eksploatuojami mažiau kaip 15 metų. Daugumos stočiu ir tarpstočiu signalizacijos iranga suprojektuota pagal keturiasdešimties, trisdešimties metu senumo tipinius projektus. Šie techniniai projektai ir irenginiai nebeatitinka šiuolaikinių saugaus traukinių eismo ir vežimų organizavimo reikalavimu.

Idiegus naujus, šių dienų reikalavimus atitinkančius signalizacijos įrenginius ženkliai sumažètų neigiamų faktorių, turinčių įtakos traukinių eismo saugumui ir eismo intensyvumui, krovinių bei vagonu apyvartai ir kitiems geležinkelių transporto eismo rodikliams. Siekiant integruotis i ES transporto tinklus ir užtikrinti aukštos kokybès transporto paslaugas, pasenusių eismo valdymo ir kontrolès sistemų, irenginių keitimas bei modernizavimas Lietuvos geležinkelyje yra vienas pagrindinių geležinkelių infrastruktūros pertvarkymo tikslų.

\section{Eismo valdymo sistemų kūrimo apžvalga}

Pirmosios kompiuterinès geležinkelių eismo valdymo sistemos pradètos naudoti 1970-jų metú pabaigoje. Tolesnis jų plitimas įvairiose šalyse daugeliu atvejų priklausė nuo nacionalinių transporto eismo valdymo sistemų diegimo geležinkeliuose koncepcijų. Šiuolaikines mikroprocesorines eismo valdymo sistemas gamina Europoje ir pasaulyje plačiai žinomos švedų „Bombardier Transportation“ (ankstesnis pavadinimas - ADTRANZ), SIEMENS (Vokietija), ALCATEL (Austrija) ir ALSTOM (Ispanija) įmonès. Šios įmonès savaip sprende eismo automatizavimo sistemų kūrimo klausimus. 1978 metais pirmają tokią elektroninę valdymo sistemą EBILOCK Gioteburge įdiegè Švedijos bendrovè „Ericsson Signal“. Dabar ši imonè priklauso bendrovei ADTRANZ, kuri susiliejo su transporto sektoriuje dabar neegzistuojančiu koncernu AEG. EBILOCK sistemai priskiriamas visas eismo valdymo sistemu spektras. Tai EBILINE tarpstočio automatinès blokuotès sistema, pervažos signalizacijos EBIGATE sistema. Be to, dar sukurta traukinių eismo valdymo centro sistema EBICOS bei automatinès lokomotyvų signalizacijos sistema EBICAB. Šiuo metu EBILOCK sistema daugiausiai naudojama Skandinavijoje. 


\section{Eismo valdymo sistemų palyginimas}

Penkiasdešimt šešiose AB „Lietuvos geležinkeliai“ stotyse traukinių eismą valdo blokinè eismo valdymo sistema, dvidešimt šešiose - relinè, devyniolikoje - rakinamoji ir tik vienuolikoje - mikroprocesorinè.

Eismo valdymo sistemos pagal jų eksploatacijos pradžios laiką pasiskirsto taip:

- iki 1970 metu - 9;

- iki 1980 metu - 35;

- iki 1990 metu - 39;

- iki 2000 metu - 9;

- po 2000 metu - 20 .

Traukinių eismui tarpstočiuose valdyti dažniausiai irengiama kelio blokuotè (Techninio geležinkelių naudojimo nuostatai 1998). Automatinè blokuotè - tai traukinių eismo tvarkymo pagal tarpstočio šviesoforus įranga. Kelių, kuriuose irengta automatinè blokuotè, ilgis yra $545 \mathrm{~km}$. Iš jų vienkelių ruožų - $268 \mathrm{~km}$, dvikelių ruožu $277 \mathrm{~km}$.

Relinè pusiau automatinè blokuotè - tai intervalinè traukinių eismo tvarkymo neintensyvaus eismo ruožuose iranga (Geležinkelių eismo taisyklès 2000). Kelių, kuriuose irengta pusiau automatinè blokuote ilgis yra $1052 \mathrm{~km}$. Iš jų vienkelių ruožų - $968 \mathrm{~km}$, dvikelių ruožų $-85 \mathrm{~km}$.

Tarpstotis, kuriame irengta automatinès kelio blokuotès sistema, yra suskaidytas į atskirus 1-2,6 kilometro ilgio ruožus, o kiekvienas blokuojamas ruožas atitveriamas tarpstočio šviesoforais (Lingaitis ir kt. 2009). Ši sistema kontroliuoja traukinio buvimo tarpstotyje vieta, todèl leidžiamas kelių ta pačia kryptimi vienu metu važiuojančių traukinių eismas to paties tarpstočio atskiruose blokuojamuosiuose ruožuose.

Pusiau automatinès kelio blokuotès sistema traukinio buvimo vietos tarpstotyje nekontroliuoja, todèl šiuo atveju tame pačiame tarpstočio kelyje vienu metu gali būti tiktai vienas traukinys.

Idiegtos automatinè ir pusiau automatinè kelio blokuotės sistemos mažiausiai $25 \%$ padidina pralaidumą vienkeliame ruože. Tai leidžia išvengti brangiai kainuojančių antrujų kelių tarpstočiuose tiesimo. Mikroprocesorinių automatinès kelio blokuotès sistemų su centralizuotu valdymo ir kontrolès irangos išdèstymu iddiegimas išlaidas sumažina iki $60 \%$ (Lingaitis ir $k t$. 2009).

\section{Geležinkeliais vežamų krovinių analizė}

Skirtingais kelio ruožais vežamų krovinių kiekis ženkliai skiriasi, todèl prieš parenkant ir įdiegiant naują eismo valdymo sistemą, būtina išanalizuoti modernizuojamo ruožo apkrovimo netolygumus bei įvertinti ruožo efektyvumą.

Ruožu vežamų krovinių netolygumo rodiklis yra grižtamumo koeficientas. Jis rodo tuščia kryptimi vežamų krovinių santyki su krauta kryptimi vežamu krovinių kiekiu.

Vežimų apkrovimo netolygumo rodiklio koeficientas - tai maksimalus per mėnesi vežtų krovinių kiekio santykis su vidutiniu mėnesiniu vežtu krovinių kiekiu per metus. Šio koeficiento vidutinè reikšmè visiems kroviniams - 1,05. Dèl vežimų geležinkeliais netolygumo būtina turèti krovinių praleidžiamumo rezerva, lokomotyvų ir vagonu atsargas, išlaikyti papildomus darbuotojus, kurie visiškai išnaudojami vežimų efektyvumui pasiekus maksimumą. Tokiu laikotarpiu ruožuose atsiranda žinomų traukinių praleidžiamumo sunkumų.

Ruožų apkrovimo netolygumas vertinamas netolygumo koeficientu:

$k_{\text {apkr.netol. }}=\frac{L_{r}}{\sum m \cdot s}$,

čia: $L_{r}$ - ruožo ilgis, $\mathrm{km} ; m$ - rida; $s$ - laikas.

Ruožų apkrovai ịvertinti pasirinkti: du dvikeliai ruožai ir keturi vienkeliai ruožai (žr. lentelę).

Atlikus ruožų apkrovos ir ridos netolygumų analizes galima teigti, kad ruožai apkrauti netolygiai. Ivertinus ruožu apkrovos netolygumo koeficientus galima efektyviau planuoti riedmenų naudojimą ir racionaliau parinkti ruože diegiamas modernias eismo valdymo sistemas.

\section{Signalizacijos sistemų gedimų ir sulaikytų traukinių analize}

Atlikus gedimų ir sulaikytų traukinių analizę (žr. pav.) matyti, kad sulaikytų traukinių skaičius akivaizdžiai priklauso nuo signalizacijos gedimų skaičiaus (2001-2007 metų signalizacijos irenginių veikimo sutrikimų analizè). Per kelis paskutinius metus diegiant naujas eismo valdymo ir signalizacijos sistemas, signalizacijos gedimų skaičius sumažèjo nuo 344 iki 240, o tuo pačiu ženkliai, t. y. nuo 135 iki 101 sumažèjo ir sulaikytų traukinių skaičius. Tai rodo, kad signalizacijos įrenginių modernizavimas stotyse ir tarpstočiuose naudingas, nes mažina signalizacijos gedimų ir sulaikytų traukinių skaičių.

Nuo traukinių, sulaikytų dèl signalizacijos gedimų, skaičiaus priklauso bendra keleivių ir krovinių vežimo trukmè. Kuo ilgiau traukiniai užtruks stotyse ar tarpstočiuose, tuo didesnių nuostolių patirs geležinkelių trans- 
Lentelè. Ruožų ridos netolygumų analizè

Table. The analysis of non-uniformity of runs on various routes

\begin{tabular}{|l|c|c|c|c|c|}
\hline \multicolumn{1}{|c|}{ Ruožo pavadinimas } & $X_{1}$ & $X_{2}$ & $X_{3}$ & $X_{4}$ & $\bar{X}$ \\
\hline Kaunas-Jiesia & 0,16300 & 0,13000 & 0,13600 & 0,01710 & 0,01500 \\
\hline Lentvaris-Vievis & 0,00031 & 0,00032 & 0,00033 & 0,00030 & 0,00032 \\
\hline Valčiūnai-Kyviškès & 0,00076 & 0,00078 & 0,00084 & 0,00074 & 0,00078 \\
\hline Šeštokai-Kalvarija & 0,02030 & 0,01570 & 0,01770 & 0,01880 & 0,01813 \\
\hline Vaidotai- Paneriai & 0,00260 & 0,00240 & 0,00180 & 0,00200 & 0,00220 \\
\hline Palemonas-Gaižiūnai & 0,00550 & 0,00480 & 0,00440 & 0,00400 & 0,00468 \\
\hline Pastaba: $X_{1}, X_{2}, X_{3}, X_{4}-$ ketvirtine lokomotyvo rida; $\bar{X}-$ vidutinè lokomotyvo rida. \\
\hline
\end{tabular}

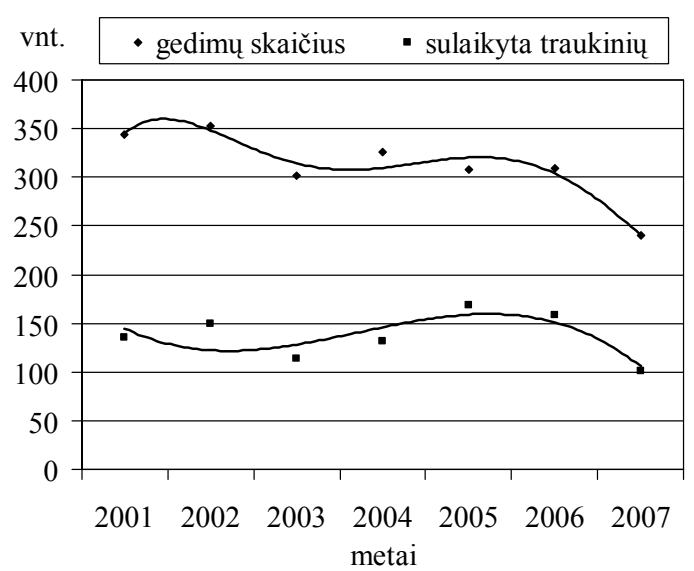

Pav. Signalizacijos sistemų gedimų ir sulaikytų traukinių dinamika

Fig. The dynamics of failures of signaling systems and delayed trains

portu krovinius vežančios bendrovès. Norint, kad keleivių ir krovinių vežimai Lietuvos geležinkeliais neužtruktu ilgiau nei gretimose šalyse, šių vežimų apimtys didètų, reikia siekti, kad eismo valdymo ir signalizacijos gedimu ir sulaikytų traukinių skaičius būtų minimalus.

\section{Mikroprocesorinès eismo valdymo sistemos įdiegimo sąnaudos}

Automatikos ir ryšių ūkis vaidina labai svarbu vaidmeni garantuojant saugu ir tikslų traukinių eismą. Didinant traukinių greiti bei kelių praleidžiamaji pajègumą tampa labai svarbus nenutrūkstamas ir patikimas ryšys tarp geležinkelių transporto padalinių, laiku perduodama informacija ir kiti nurodymai. Nuo automatikos, telemechanikos bei ryšių plètojimo priklauso vežimų kultūra bei efektyvus geležinkelių transporto priemonių naudojimas. Krovinius vežant kelių rūšių transporto priemonėmis, tai lemia ir kitų rūšių transporto priemonių naudojimo efektyvumą. Automatikos ir ryšių ūkyje dirba 5,5\% darbuotojų ir jame sunaudojama 4,8\% vežimams skirtų lèšų.
Automatinè blokuotė užtikrina eismo saugumą ir didina praleidžiamaji pajègumą. Dvikeliuose ruožuose su keturženkliais šviesoforais gali būti nustatytas 3 min., o su triženkliais - 6-8 min. intervalas tarp traukinių. Dvikeliuose ruožuose, kuriuose yra irengta automatinè blokuotè, o stotyse - elektrinis iešmų perjungimas, praleidžiamaji pajègumą galima padidinti iki 180-220 traukinių porų per parą, o tai yra 3-3,5 karto daugiau nei ruožuose, kuriuose irengta telefono telegrafo sistema ir 2-2,5 karto daugiau nei ruožuose, kuriuose irengta automatinè blokuotè.

Idiegus naują modernią iešmu ir signalų valdymo irangą iš vieno centro galima valdyti iešmus bei signalizacijos irenginius visame $150-200 \mathrm{~km}$ ruože. Gerokai sumažèja budinčių iešmininkų postų bei stoties budètojų skaičius.

Stotyse įrengiama elektrinė iešmų ir signalų centralizacijos iranga 15-20\% padidina stoties ir aplinkinių tarpstočiu praleidžiamaji pajègumą. Naudojant relinę mikroprocesorinę eismo valdymo sistemą, relių skaičius vidutiniškai sumažèja nuo 80 iki 23 skaičiuojant vienam stoties iešmui (Geležinkeliai. Bendrasis kursas 2009).

Kai prietaisai valdomi elektra, maršruto paruošimas trunka nuo $10 \mathrm{~s}$ iki $1 \mathrm{~min}$, o kai prietaisai valdomi rankiniu būdu, tai trunka 10-15 min.

Pagrindinès eksploatacinès sąnaudos automatikos ūkyje susidaro dèl išlaidų medžiagoms, degalams, elektros energijai, darbo užmokesčiui ir kitoms išlaidoms.

Apskaičiuosime mikroprocesorinès eismo valdymo sistemos įdiegimo stotyje sąnaudas:

- signalizacijos įrenginiai - 335 tūkst. Lt;

- lauko įranga ir kabeliai - 629 tūkst. Lt;

- posto vidaus iranga ir kabeliai - 1,9 mln. Lt;

- signalizacijos įrenginių irengimo ir bandymo išlaidos -653 tūkst. Lt.

Iš viso signalizacijos įrenginiams, jų irengimui ir bandymams bus sunaudota daugiau nei 3,5 mln. Lt. 
Šios sistemos irengimas pakankamai brangus, bet tai yra ilgalaikè ir įvairiapusišką naudą teikianti investicija.

\section{Mikroprocesorinės eismo valdymo sistemos atsiper- kamumas}

Modernizavus stotis ir iddiegus naują mikroprocesorinę eismo valdymo sistemą, akivaizdžiai sumažès irenginiu skaičius, todèl mažès ir sutrikimų skaičius, didès visos sistemos patikimumas, padidès traukinių eismo saugumas ir pagerès darbo sąlygos. Didelį relių skaičių, gremėzdiškus pultus ir švieslentes pakeis mikroprocesoriai ir patogios automatizuotos operatoriu darbo vietos. Bus sumažintas eismo organizavimo darbuotojų, iešmininku skaičius. Mažų stočių irenginius bus galima valdyti ir kontroliuoti jų darbą iš centrinio valdymo skyriaus.

Žinodami stotyse dirbančių darbuotojų skaičių ir pareigas galime apskaičiuoti lěšų darbuotoju algoms poreiki.

Skaičiuojant atlygi už ištarnautus metus daroma prielaida, kad darbuotojai vidutiniškai dirbo maždaug 10 metu, o tai sudaro $15 \%$ tarifinio atlygio. Ivertinamas premijos dydis - $50 \%$ dirbantiems lauko salygomis ir $45 \%$ - visiems kitiems.

Stotyse, kuriose irengta rakinamoji eismo valdymo sistema (Pabradè) algoms per metus išmokama daugiau kaip 600 tūkst. Lt.

Stotyse, kur irrengta relinè (Dūkštas) ir blokinė (Kirtimai) eismo valdymo sistemos algoms per metus išmokama daugiau nei 400 tūkst. Lt.

Irengus mikroprocesorinę eismo valdymo sistemą algoms išmokos sudaro tik 150 tūkst. Lt.

Jei rakinamaja eismo valdymo sistemą pakeisime mikroprocesorine, ji atsipirks po 7,5 metu, reline ir blokine - po 14 metu.

\section{Išvados}

1. Didesnè dalis - apie $80 \%$ signalizacijos irenginiu yra pasenę ir neatitinka saugaus traukiniu eismo ir vežimų organizavimo reikalavimų.

2. Naujos mikroprocesorinès eismo valdymo sistemos turi nemažai privalumų. Pagrindiniai jų - didesnis valdymo galimybių spektras, mažesni gabaritai.

3. Idiegus mikroprocesorinę eismo valdymo sistemą pagerès stoties eksploatavimo rodikliai: iki 3 kartų sumažès aptarnaujančio personalo skaičius, sumažès įrenginiu priežiūros sudètingumas, neišaiškintu sutrikimu skaičius, iki 2 kartų padidès riedmenų pralaidumas.
4. Apskaičiuota, kad rakinamosios eismo valdymo sistemos keitimas mikroprocesorine atsipirktu po 7,5 metu.

5. Siūloma keisti pusiau automatinę kelio blokuotę i automatinę, relinę eismo valdymo sistemą i mikroprocesorinę, nes tokiu būdu galima padidinti vežamų krovinių ir keleivių skaičių Lietuvos geležinkeliais.

\section{Literatūra}

2001-2007 metu signalizacijos irenginiu veikimo sutrikimu analizés. Vilnius. AB „Lietuvos geležinkeliai“ geležinkelių infrastruktūros direkcijos, automatikos, ryšių ir elektros tiekimo tarnyba.

Geležinkeliu eismo taisyklès. 2000. Informacijos ir leidybos centras. $263 \mathrm{p}$.

Lingaitis, L. P.; Liudvinavičius, L.; Butkevičius, J.; Podagèlis, I.; Sakalauskas, K.; Vaičiūnas, G.; Bureika, G.; Gailienè, I.; Petrenko, V.; Subačius, R. 2009. Geležinkeliai. Bendrasis kursas. Vilnius: Technika. 280 p.

Techninio geležinkeliu naudojimo nuostatai. 1998. Vilnius: Informacijos ir leidybos centras. $127 \mathrm{p}$.

\section{THE ANALYSIS OF RAIL TRAFFIC CONTROL SYSTEMS}

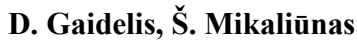

Abstract

The systems used for rail traffic control are compared. Their advantages and disadvantages are analysed.

The present and future development of rail traffic control systems in various countries is considered.

The possibility of adapting these microprocessor-based traffic control systems to the conditions of Lithuania is analysed. For this purpose, the analysis of goods transported by Lithuanian railways is made, and the non-uniform amount of goods transported on different road sections is evaluated.

The number of the delayed trains due to the failure of traffic control systems in recent years is determined, the cost of installing a new microprocessor-based traffic control system at the railway station, as well as its repay time and the demand for employees are calculated.

Keywords: railway transport, traffic control systems. 